\title{
Sera from Preeclampsia Patients Elicit Symptoms of Human Disease in Mice and Provide a Basis for an in Vitro Predictive Assay
}

\author{
Satyan Kalkunte, ${ }^{*}$ Roland Boij, ${ }^{\dagger}$ Wendy Norris, ${ }^{*}$ \\ Jennifer Friedman, ${ }^{\star}$ Zhongbin Lai, ${ }^{*}$ \\ Jonathan Kurtis, ${ }^{\ddagger}$ Kee-Hak Lim, ${ }^{\S}$ \\ James F. Padbury, ${ }^{*}$ Leif Matthiesen, ${ }^{\pi}$ \\ and Surendra Sharma* \\ From the Department of Pediatrics, "Women and Infants \\ Hospital-Warren Alpert Medical School, and the Lifespan Center \\ for International Health Research, ${ }^{\ddagger}$ Brown University, \\ Providence, Rhode Island; the Faculty of Health Sciences, ${ }^{\dagger}$ \\ Linkoping University Medical School, Linkoping, Sweden; the \\ Department of Obstetrics and Gynecology, ${ }^{\S}$ Harvard Medical \\ School, Boston, Massachusetts; and the Department of Obstetrics \\ and Gynecology, "Helsingborg Hospital, Helsingborg, Sweden
}

Early diagnosis and treatment of preeclampsia would significantly reduce maternal and fetal morbidity and mortality. However, its etiology and prediction have remained elusive. Based on the hypothesis that sera from patients with preeclampsia could function as a "blueprint" of causative factors, we describe a serumbased pregnancy-specific mouse model that closely mirrors the human condition as well as an in vitro predictive assay. We show that a single administration of human preeclampsia serum in pregnant $\mathrm{IL}_{-10}{ }^{-/-}$mice induced the full spectrum of preeclampsia-like symptoms, caused hypoxic injury in uteroplacental tissues, and elevated soluble fms-like tyrosine kinase 1 and soluble endoglin, markers thought to be related to the disease. The same serum sample(s) induced a partial preeclampsia phenotype in wild-type mice. Importantly, preeclampsia serum disrupted cross talk between trophoblasts and endothelial cells in an in vitro model of endovascular activity. Disruption of endovascular activity could be documented in serum samples as early as 12 to 14 weeks of gestation from patients who subsequently developed preeclampsia. These results indicate that preeclampsia patient sera can be used to understand the pregnancy-specific disease pathology in mice and can predict the disorder. (AmJ Pathol 2010, 177:2387-2398; DOI: 10.2353/ajpath.2010.100475)
Preeclampsia is a systemic syndrome that occurs in about $5 \%$ to $8 \%$ of pregnancies worldwide. ${ }^{1}$ This disorder is diagnosed in the second half of pregnancy and represents a leading cause of maternal and fetal mortality and morbidity. Since the preeclampsia-associated clinical features resolve after delivery, dysregulated placental development and function have long been thought to contribute to the pathogenesis of this pregnancy complication. ${ }^{2}$ It is surprising that, despite the abundant clinical knowledge of this syndrome, no definite etiology or predictive diagnostic tests have been identified. This situation is exacerbated by the likely multifactorial etiologies that contribute to the symptom complex we label as preeclampsia. Heterogeneity of the disorder is further exemplified by the range of clinical manifestations that present with or without fetal growth restriction, mild or severe pathology, resulting in induced preterm or term delivery, and the influence of a wide range of maternal factors. ${ }^{3,4}$ At the maternal-fetal interface, superficial placentation coupled with immune maladaptation, imbalance in angiogenic growth factors, and increased placental debris in the maternal circulation has been suggested to contribute to the disease. ${ }^{5-9}$ Because of the placental deficiencies and ensuing maternal syndrome, preeclampsia is considered to be a culmination of at least two stages of disorder. The first stage is characterized by placental ischemia leading to release of soluble factors from placenta, which is thought to initiate the second stage of maternal response. ${ }^{10,11}$ In this context, in-

Supported by NIH P20RR018728 and by the Rhode Island Research Alliance Collaborative Research Award 2009-28 to S.S. and grant 5U01 Al066050 to J.F. This work was initiated with funds from the American Diabetes Association Terry and Louise Gregg Diabetes in Pregnancy Award (01-04-TLG-14) with a focus on developing a mouse model for gestational diabetes.

Accepted for publication July 8, 2010.

None of the authors disclosed any relevant financial relationships.

Supplemental material for this article can be found on http://ajp. amjpathol.org

Address reprint requests to Surendra Sharma, M.D., Ph.D., Department of Pediatrics, Women and Infants Hospital, 101 Dudley St, Providence, RI 02905. E-mail: ssharma@wihri.org. 
creased circulating levels of anti-angiogenic factors, soluble fms-like tyrosine kinase 1 (sFlt-1) and soluble endoglin (sEng), have been proposed as the soluble components possibly initiating the maternal symptoms. These factors are reported to be altered several weeks preceding clinical disease. ${ }^{6,12-14}$ However, the etiological heterogeneity is reflected by the fact that preeclampsia also occurs in some women with low circulating sFlt-1 and sEng levels and high placenta growth factor (PIGF). 6,13,15 Recent studies have also described high circulating levels of autoantibodies against angiotensin receptor-1 (AT1-AAs) in women with preeclampsia. ${ }^{16,17}$ Surprisingly, when the anti-angiogenic factors and AT1AAs were tested in rodent models, they resulted in only partial manifestation of the human condition. This suggests regulatory contributions by additional environmental, genetic, and/or nutritional factors in the onset of the syndrome. ${ }^{18} \mathrm{~A}$ less appreciated aspect of these elegant studies is the same experimental paradigm leads to induction of hypertension and proteinuria in nonpregnant animals. Whether this is pointing to upstream regulatory factors that trigger the placental pathology or reflects a different pathophysiological response than "true" preeclampsia is not known. Moreover, AT1 receptor antagonist therapy or hypertension controlling drugs such as angiotensin converting enzyme (ACE) inhibitors are not the choice of treatment for preeclampsia. ${ }^{19}$

The relatively late onset of clinical presentation and lack of well defined in vitro and in vivo models have further hindered our understanding of the causative factors of the preeclampsia syndrome and the development of therapeutic interventions. Several reports have described mouse models that mimic only partial features of the human condition or have been questioned for similar features in nonpregnant mice or lack of features under environmentally challenged conditions. ${ }^{20-27}$ Thus, there is an urgent need for a well defined pregnancy-specific experimental model that can closely mirror the human condition and encompasses the contribution of predisposing factors. We and others have demonstrated in both human and mouse models that interleukin (IL)-10 is a critical cytokine for normal pregnancy outcome, particularly in response to inflammatory triggers. ${ }^{28-31}$ Importantly, pregnant IL-10 $10^{-/-}$animals were found to be highly sensitive to low doses of inflammatory triggers leading to fetal demise, premature delivery, and intrauterine growth restriction (IUGR), features common to preeclampsia. ${ }^{32-34}$ This suggests that IL-10 $10^{-1-}$ mice may provide a model system for studying pregnancy complications including preeclampsia. Indeed, reduced IL-10 has been described in placental tissue from preeclampsia deliveries. ${ }^{35,36}$

The endovascular transformation of spiral arteries, under the influence of the triumvirate of endothelial cells, trophoblasts, and uterine natural killer cells, is essential to the maintenance of placental perfusion. ${ }^{37-39}$ Although elegant arguments have been made for disordered velocity of blood flow in causing placental pathology, ${ }^{40}$ dysregulated endovascular cross talk between trophoblasts and endothelial cells in spiral artery remodeling remains an important but understudied pathway. We pos- ited that this interaction provides a basis for an in vitro model using capillary tube formation in three-dimensional culture on matrigel. We have recently demonstrated that formation of tube-like structures between endothelial cells and first trimester trophoblasts, mimicking spiral artery remodeling, could be readily accomplished, but required the presence of normal pregnancy serum. ${ }^{41}$ This implies that pregnancy serum contains necessary components and can be used as a "blueprint" to provide a suitable in vitro milieu to mirror events at the maternalfetal interface.

We demonstrate here that a single administration of preeclampsia serum in pregnant $\mathrm{IL}-10^{-1-}$ mice induces the full spectrum of clinical features associated with human preeclampsia, including elevated blood pressure, proteinuria, IUGR, renal pathology, poor spiral artery remodeling, and excess production of sFlt-1 and sEng. Preeclampsia serum induced hypoxic injury in uteroplacental units. Control serum from nonpregnant healthy women exhibited no such effects and administration of preeclampsia serum to nonpregnant animals also failed to induce any preeclampsia-like features. Further, we show in the in vitro model of endothelial cell-trophoblast interaction that endovascular capillary tube formation is significantly disrupted by preeclampsia serum from patients with either mild or severe disease. These pathological effects of preeclampsia serum in mice provide avenues to study pregnancy-specific mechanistic and preventive pathways and present novel opportunities for predicting this enigmatic disease.

\section{Materials and Methods}

\section{Patients and Serum Collection}

Preeclampsia was defined by systolic blood pressure of more than $140 \mathrm{mmHg}$ and diastolic blood pressure of more than $90 \mathrm{mmHg}$ after 20 weeks' gestation in a previously normotensive patient and new onset proteinuria (>300 mg of protein in a 24-hour urine collection or a random urine protein/creatinine ratio of $>0.3$ ). Patients with baseline hypertension, proteinuria, renal disease, diabetes, and twin pregnancy were excluded. For the purposes of this study, patients were divided into groups with mild and severe preeclampsia on the basis of the recently published American College of Obstetricians and Gynecologists criteria. ${ }^{42}$ Healthy, normotensive pregnant women (the "normal" group) were included as controls. Blood was obtained from normally cycling women and pregnant women during 12 to 14,24 to 27 , and 32 to 36 weeks of pregnancy with informed consent, under the approved protocols by the institutional review boards of participating institutes, Women and Infants Hospital of Rhode Island, Beth Israel Deaconess Medical Center, Lifespan-Rhode Island Hospital, and Linkoping University Hospital (Linkoping, Sweden). Serum was separated and frozen as aliquots at $-80^{\circ} \mathrm{C}$ until further use. The clinical characteristics of subjects are provided in

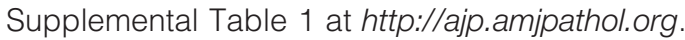




\section{Animal Studies}

All animal protocols were approved by the Lifespan Institutional Animal Care and Use Committee. C57BL/6 wild type or IL-10 $10^{-1-}$ mice were housed and mated in a specific pathogen-free facility under the care of the Central Research Department of Rhode Island Hospital. All mating experiments were repeated at least three times with at least four to six mice per treatment. The day of vaginal plug appearance was designated gestational day (gd) 0 . We administered i.p injection of severe $(n=8)$ or mild $(n=5)$ preeclampsia serum $(100 \mu \mathrm{l})$ per mouse or an equivalent volume $(100 \mu \mathrm{l})$ of normal pregnancy serum ( $n=9$ ) as control to pregnant C57BL/6 wild type or $\mathrm{IL}-10^{-1-}$ mice on gd 10. On gd 17, after the blood pressure recoding, the animals were euthanized, the uteroplacental units were photographed, and fetal weights were recoded. Similarly nonpregnant female mice were injected for comparative analysis after 7 days. For monitoring the influence of AT1-AAs in the serum samples, pregnant $\mathrm{IL}-10^{-1-}$ mice were co-injected with normal pregnancy serum or severe preeclampsia serum in the presence or absence of losartan potassium (LK, Sigma Aldrich, St. Louis, MO, $0.24 \mathrm{mg}$ ) or an antibody neutralizing seven-amino acid peptide (7-aa, Baylor College of Medicine, Houston, TX, $1.5 \mathrm{mg}$ ) on gd 10 and animals were processed on gd 17 as described.

\section{Assessment of Proteinuria}

On gd 16, the animals were transferred to individual metabolic cages. Samples of urine were collected over 24 hours, aliquot, and stored at $-80^{\circ} \mathrm{C}$ until further analysis. Total urinary albumin was measured by using Albumin (mouse) enzyme-linked immunosorbent assay (ELISA) kit (ALPCO Diagnostics, Salem, NH), which is based on double antibody sandwich ELISA according to the manufacturer's protocol. The kit is highly sensitive and can detect albumin levels at 1:10,000 dilutions. To normalize the albumin, urinary creatinine was measured by using Metra Creatinine Kit (Quidel Corporation, San Diego, CA), which is based on modified Jaffe method according to the manufacturer's protocol. Proteinuria was represented as the ratio of urinary albumin to creatinine and was expressed as microgram per milligram.

\section{Measurement of Blood Pressure}

Blood pressure was recorded by an established tail-cuff method that utilizes a programmed sphygmomanometer. ${ }^{43}$ The animals were adapted for 5 minutes in a warming test chamber (IITC Life Science Inc, Woodland Hills, $\mathrm{CA})$ at a controlled temperature $\left(35^{\circ} \mathrm{C}\right)$. These measurements were carried out on gd 17 of pregnancy by using DigiMed blood pressure analyzer (MicroMed, Louisville, $\mathrm{KY}$ ). Each measurement of blood pressure was an average of three readings at a 1-minute interval from a number of animals ( five to six each). Systolic blood pressure was compared with pregnant mice with and without treatments. Nonpregnant animals were also treated with normal pregnancy serum or preeclampsia serum and after 7 days, blood pressure was similarly recorded. Data were analyzed by using Digi-Med System Integrator Model 400 (DMSI-400; MicroMed, Louisville, KY).

\section{Assessment of Renal Pathology}

Kidney tissue were harvested from gd 17 mice, fixed in $10 \%$ buffered formalin, and were stained with hematoxylin/eosin and periodic acid Schiff for histopathological examination. A number of randomly selected glomeruli were assessed by at least two pathologists. Morphological changes were recorded by using SPOT Advanced software (Diagnostic Instruments, Inc, Sterling Heights, $\mathrm{MI})$ at $\times 100$ magnification (Nikon Eclipse 80i microscope; Avon, MA).

\section{Evaluation of Spiral Arteries}

Placental morphology and spiral arteries were monitored by harvesting uteroplacental units on gd 13, fixed and paraffin embedded, and sectioned and stained with H\&E staining as described. ${ }^{44}$ We then acquired the images with a Nikon Eclipse 80i microscope (Nikon) at $\times 4$ magnification. Morphometric analysis of spiral arteries was carried out by using the SPOT Advanced software (Diagnostic Instruments, Inc) at $\times 40$ magnification (Nikon Eclipse 80i microscope). Average area of spiral arteries (at least six per implantation site) were calculated from three independent animals per group as reported elsewhere. ${ }^{34}$

\section{Assessment of Hypoxia}

In vivo hypoxia was detected by using the marker EF5, a gift from Dr. Cameron Koch. ${ }^{45,46}$ EF5 (2-(2-nitro-1H-imidazol-1-yl)-N-(2,2,3,3,3-pentafluoropropyl) acetamide) is reduced under hypoxic conditions and the reduced form reacts with cellular macromolecules, thereby demarcating regions of hypoxia. ${ }^{47-49}$ Briefly, EF5 (10 $\left.\mu \mathrm{mol} / \mathrm{L}\right)$ was administered i.p. 4 hours before harvesting the uteroplacental units on gd 14. The units were snap-frozen and $10-\mu \mathrm{m}$ sections were processed and probed for bound EF5 by using ELK3-51 antibody (1:30) as described. ${ }^{50}$

\section{Western Blotting}

To further confirm that treatment with preeclampsia serum did indeed induce hypoxia, placental units were harvested between gd 12 and 14 and were lysed with cell lysis buffer (Cell Signaling, Danvers, MA). The proteins from tissue lysates were separated on 12\% SDS-polyacrylamide gels and blotted onto polyvinylidene difluoride membranes and probed with antibodies for hypoxia-inducible factor (HIF 1 $\alpha$ ) (Santa Cruz Biotechnology, Santa Cruz, CA) and $\beta$-actin (BD Biosciences, San Jose, CA). Enhanced Chemiluminescence (ECL) (Amersham Biosciences, Piscataway, NJ) was used to visualize the 
bands, and we recorded them by using Konica SRX 101A developer.

\section{Enzyme-Linked Immunosorbent Assay}

To assess the biochemical changes associated with preeclampsia, blood from gd 17 mice were collected by cardiac puncture. Serum was separated from cellular mass by brief centrifugation and stored at $-80^{\circ} \mathrm{C}$ until further use. The serum levels of sFlt-1 and sEng (R\&D Systems, Minneapolis, MN) were measured according to the manufacturer's instructions in duplicates.

\section{Trophoblast Cells and Endothelial Cells}

Immortalized first trimester trophoblast cell line HTR8 with properties of invasive extravillous cytotrophoblasts was established and kindly provided by Dr. Charles Graham. ${ }^{47}$ HTR8 cells were grown to $\sim 80 \%$ confluence in RPMI standard growth medium and used only during eight passages. Human umbilical cord endothelial cells were obtained from Cambrex (East Rutherford, NJ) and cultured in complete endothelial basal media (EBM-2, Cambrex). All cells were maintained in standard culture conditions of $5 \%$ $\mathrm{CO}_{2}$ at $37^{\circ} \mathrm{C}$.

\section{In Vitro Three-Dimensional Tube Formation Assay}

We have recently established a serum based three-dimensional dual cell culture model to study endovascular activity involving trophoblasts and endothelial cells. ${ }^{41}$ This model was used to evaluate the differential effects of pregnancy serum. Briefly, trophoblasts or endothelial cells $\left(2.5 \times 10^{4}\right)$, labeled with cell tracker green CMFDA or cell tracker red CMTMR (Molecular Probes, Eugene, $\mathrm{OR}$ ), respectively, were co-cultured on matrigel coated plates in the presence of serum from normal pregnancy or preeclampsia. Serum-initiated endothelial cell-directed tube formation by trophoblasts was monitored and recorded as described earlier. ${ }^{41}$ For evaluating the sensitivity of the model to distinguish samples, nonpregnant female serum, normal pregnancy serum, or preeclampsia serum at term were tested at different concentrations $(1 \%, 2.5 \%, 5 \%$, and $10 \% \mathrm{v} / \mathrm{v})$ in serum free media. Interestingly, in our studies' lower concentrations of preeclampsia serum ( $1 \%$ and $2.5 \% \mathrm{v} / \mathrm{v}$ ) did not disrupt the endovascular interactions, whereas at $5 \%$ and $10 \% \mathrm{v} / \mathrm{v}$ the tube disruption was predominant, suggesting a doseresponse relationship. Based on the initial dose-related findings, we routinely used $10 \% \mathrm{v} / \mathrm{v}$ of normal pregnancy serum or preeclampsia serum for majority of studies unless specified. To evaluate the system to predict the onset of preeclampsia, serum samples from 12 to 14 ( $n=$ 18), 24 to $27(n=5)$, and 32 to $36(n=22)$ weeks of gestation were tested and compared with gestational age-matched normal pregnancy serum. The average number of tubes/vacuoles formed was quantified as described earlier. ${ }^{34,41,48}$

\section{Cytotoxicity Assay}

Endovascular disrupting activity could be either due to cytotoxicity imparted by the serum samples or due to factors that perturb the molecular signaling in the endothelial or trophoblast cells. Thus, we evaluated the cytotoxic potential of pregnancy serum on endothelial cells and trophoblasts by propidium iodide staining. Briefly, $0.25 \times 10^{6}$ endothelial cells or trophoblasts were cultured overnight in a 12-well culture plate in complete EBM-2 or RPMI media. The cells were then incubated with serum free RPMI media containing $10 \% \mathrm{v} / \mathrm{v}$ of normal pregnancy serum or preeclampsia serum for another 24 hours, harvested by cell scraping, and washed with PBS. The cells were stained with propidium iodide $(1 \mu \mathrm{g} / \mu \mathrm{l})$ by incubating at $37^{\circ} \mathrm{C}$ for 1 hour, washed, and resuspended in Fluorescence-Activated Cell Sorting (FACS) buffer. The stained cells were then acquired $(10,000$ cells) and analyzed by FACS Calibur (Becton Dickinson, Franklin Lakes, $\mathrm{NJ}$ ).

\section{Statistics}

Statistical analyses were performed by using Microsoft Excel software version 11.1.1 and Jump version 8.0.2. Normality diagnostics were first performed for all analyses to guide choice of parametric or nonparametric tests. For normally distributed data, two-tailed Student's $t$-tests were used. $P$ values less than 0.05 were considered significant. For data with poor normal distribution, the Kruskal-Wallis test was used.

\section{Results}

\section{In Vivo Effects of Human Preeclampsia Serum on Fetal Weight, Blood Pressure, and Proteinuria}

Recent reports suggest that adenoviral delivery of sFlt-1 and sEng in pregnant mice induce preeclampsia-like symptoms. However, this vector system induces much higher levels of these anti-angiogenic factors in animals when compared with levels present in serum collected from patients with preeclampsia. ${ }^{49,51}$ We screened by ELISA a series of serum samples from normal pregnancy subjects and patients with preeclampsia given a diagnosis of either mild or severe conditions. Our data on sFlt-1 and sEng show higher average values in patients with preeclampsia compared with normal pregnancy samples (Kruskal-Wallis $P<0.0001$ and $P<0.0005$, respectively; see Supplemental Figure S1 at $h$ ttp://ajp.amjpathol.org), in agreement with the published reports. ${ }^{6,13,14}$ However, we did not observe a cross-sectional relationship with the incidence of preeclampsia, as several serum samples from this group had comparable values with normal pregnancy samples (see Supplemental Figure S1 at http:// ajp.amjpathol.org). This suggests that other factors must contribute to induction of this disorder in humans. To address our hypothesis that serum could blueprint the symptoms of preeclampsia, we injected i.p. a volume of $100 \mu \mathrm{l}$ of individual serum samples from normal pregnancy $(n=9)$ or from severe $(n=8)$ or mild $(n=5)$ 
A
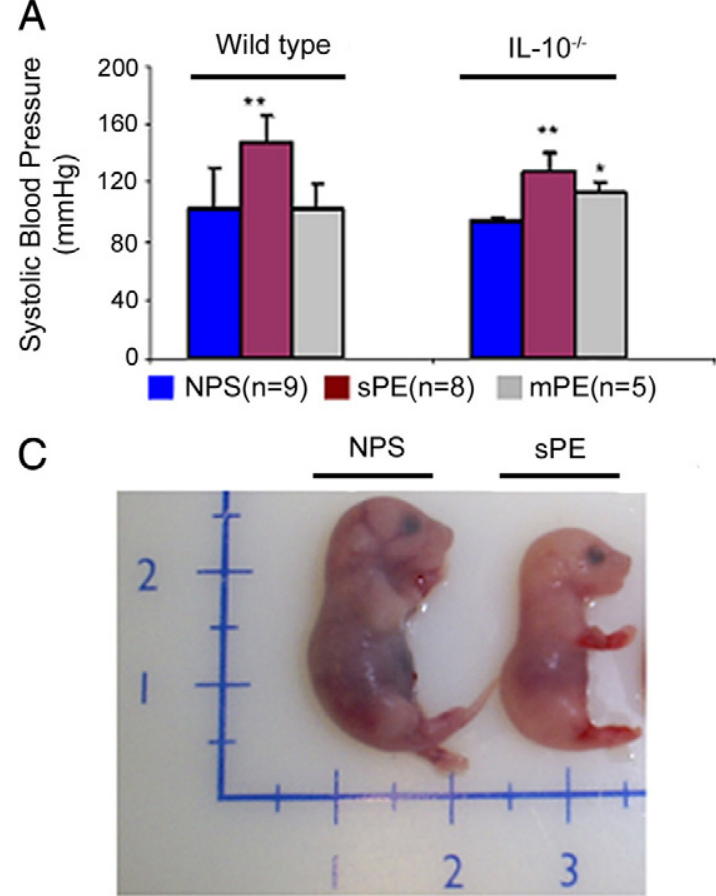

B

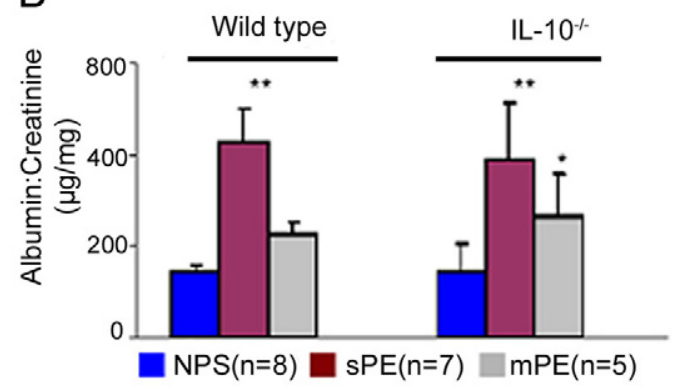

D

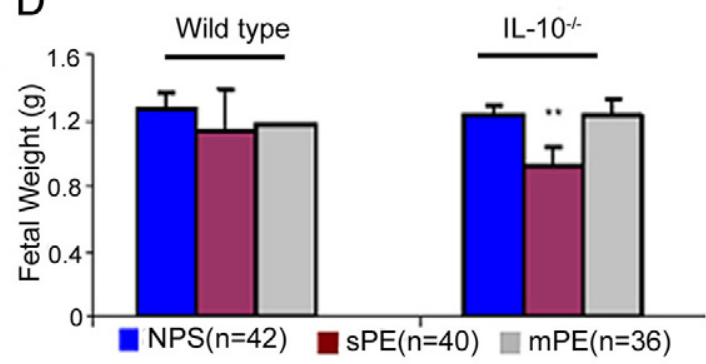

Figure 1. Preeclampsia serum induces symptoms of hypertension, proteinuria, and IUGR in pregnant IL-10 ${ }^{-/-}$mice. Pregnant wild-type or IL-10 ${ }^{-/-}$mice were injected with normal pregnancy serum (NPS), severe preeclampsia serum (sPE), or mild preeclampsia serum (mPE) on gd 10. As depicted in the figure, multiple serum samples (parentheses) were used in multiple mating experiments. A: Systolic blood pressures of pregnant mice in response to different treatments are shown. Treatment with SPE (magenta bar) induces significant hypertension in both wild-type and IL-10-/- mice when compared with treatment with NPS (blue bar). Treatment with mPE (gray bar) induces moderate hypertension only in IL- $10^{-/-}$mice compared with the NPS group. B: Proteinuria values from urine samples collected over 24-hour periods in response to different treatments are expressed as albumin to creatinine (microgram per milligram) ratios. Treatment with SPE (magenta bar) induces significant proteinuria in both wild-type and IL-10 ${ }^{-1-}$ mice compared with treatment with NPS (blue bar). Treatment with mPE (gray bar) induces moderate proteinura in IL-10 $10^{-/-}$mice without significant effect in wild-type counterparts. C: A representative photograph of a gd 17 fetus shows sPE-induced growth restriction compared with that with NPS treatment. D: Average weights of a number of fetuses (n) from wild-type or IL-10 ${ }^{-1-}$ mice are represented for different treatment groups. Treatment with sPE (magenta bar), but not mPE (gray bar) or NPS (blue bar), induces IUGR in IL-10 ${ }^{-/-}$mice with no significant effect in wild-type counterparts. All values represent the mean \pm SD of at least seven animals per group. The numbers in parentheses indicate the number of serum samples tested in the study. ${ }^{*} P<0.01 ;{ }^{* * *} P<0.05$ for PE or normal pregnancy serum groups.

preeclampsia including those with low sFlt-1 and sEng values. Serum was injected into pregnant wild type and $\mathrm{IL}-10^{-1-}$ mice on different gds (see Materials and Methods). Our pilot experiments suggested gd 10 as the most suitable time for serum administration as injection of severe preeclampsia serum on gd 8 resulted in significant intrauterine fetal death as confirmed by evaluation of uterine horns on gd 17 (see Supplemental Figure S2 at http://ajp.amjpathol.org). Similarly, injection on gds 13 to 14 did not cause any significant pathology. Accordingly, we used gd 10 for subsequent studies of the effects of preeclampsia serum administration. Injection of severe preeclampsia serum resulted in elevated blood pressure (Figure $1 \mathrm{~A}$ ) and proteinuria (Figure $1 \mathrm{~B}$ ) in $\mathrm{IL}-10^{-1-}$ mice as well as wild type counterparts. However, as seen in the Figure 1, A and B, elevated blood pressure and proteinuria were observed only in $\mathrm{IL}-10^{-1-}$ mice in response to mild preeclampsia serum samples, suggesting that IL-10 deficient mice are more susceptible to developing preeclampsia when challenged with serum from patients with this syndrome. Treatment of pregnant IL-10 $10^{-1-}$ mice with serum from severe preeclampsia invariably resulted in IUGR (Figure 1C), a phenomenon not observed with samples from mild preeclampsia. Surprisingly, fetal weights were not significantly affected in wild type mice by even severe preeclampsia samples (Figure 1D). The effects of preeclampsia serum cannot be directly attributed to human sFlt-1 and sEng because their absolute values in $100 \mu$ l samples are relatively low ( $\sim 5 \mathrm{ng}$ and $\sim 15 \mathrm{ng}$, respectively). Similarly, our observations could not be attributed to the presence of AT1-AAs in preeclampsia serum because co-treatment with $A T_{1}$ receptor antagonist losartan or neutralizing AT1 receptor epitope binding 7-amino acid peptide in $\mathrm{IL}-10^{-1-}$ mice did not reverse the abnormalities in fetal weight, blood pressure, and proteinuria (see Supplemental Figure S3, A-D, at http://ajp.amjpathol.org).

\section{Renal Pathology Is Associated with Treatment with Preeclampsia Serum}

Glomerular endotheliosis and impaired renal function are cardinal features of preeclampsia. ${ }^{52}$ To assess whether preeclampsia serum samples cause renal pathology, kidney tissue was harvested from the different treatment groups and stained as described in Materials and Methods. Figure 2A depicts the renal lesions that were observed after administration of severe preeclampsia serum and normal pregnancy serum in pregnant mice. Typical glomerular endotheliosis, characterized by obliteration of Bowman's capsule and increased infiltration of protein droplets in the 
A

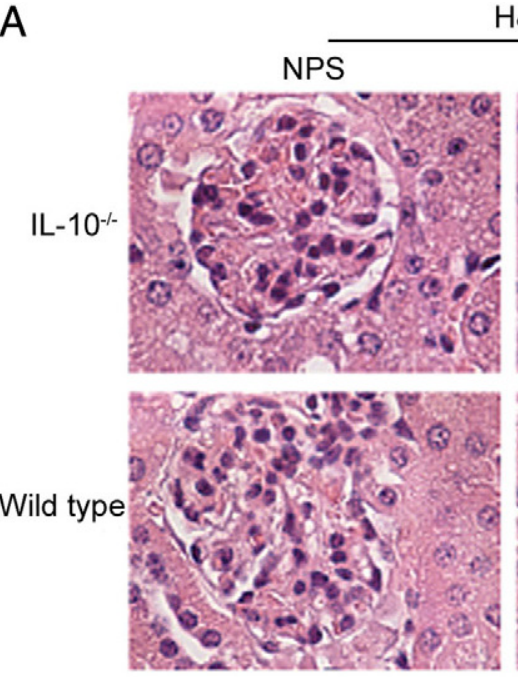

H\&E
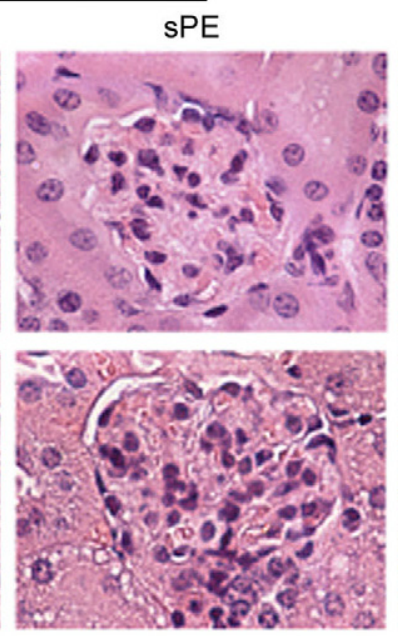

B

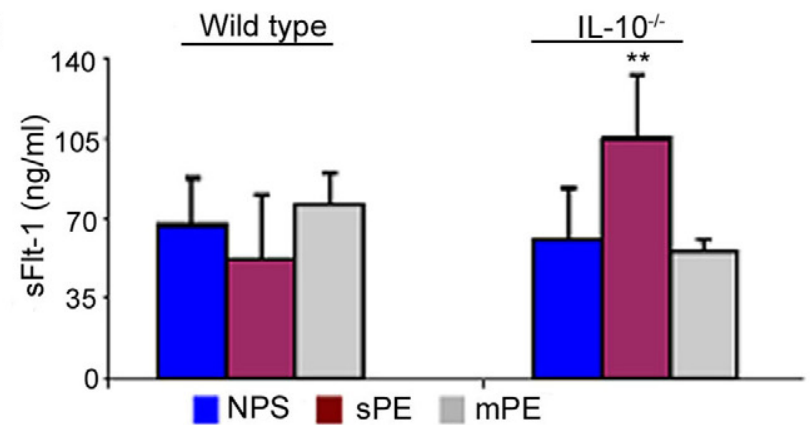

PAS
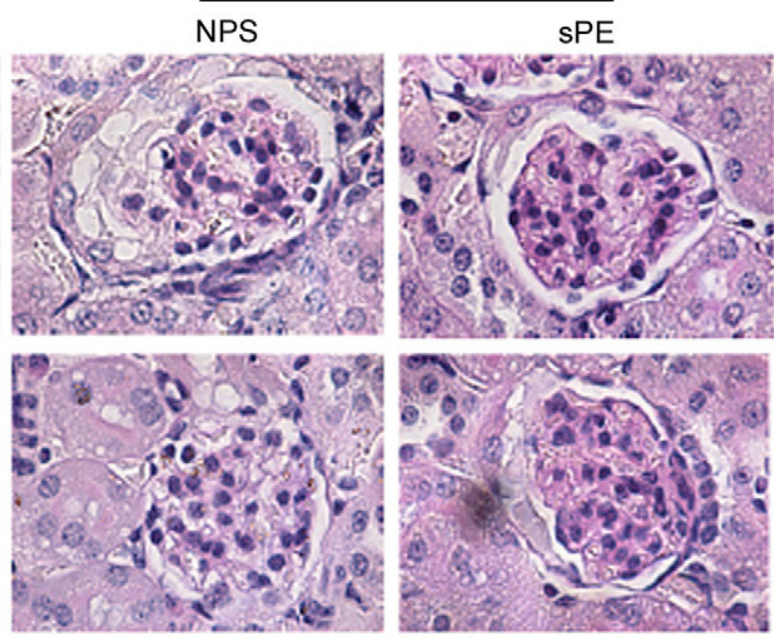

C

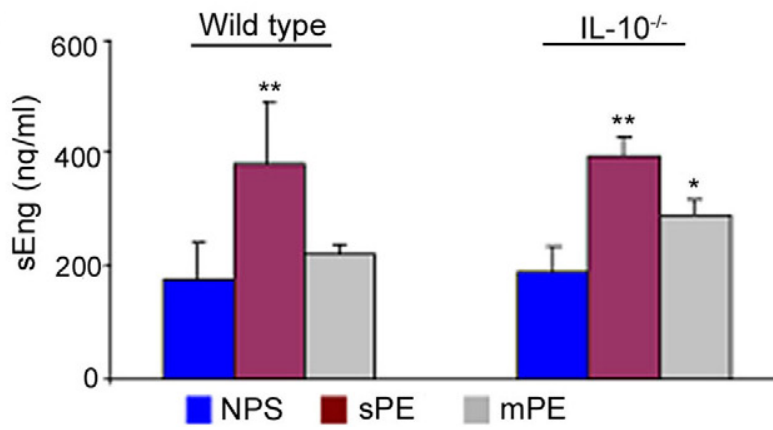

Figure 2. Preeclampsia serum induces glomerular endotheliosis and elevated sFlt-1 and sEng production. A: Histopathological analyses of renal tissue from representative NPS- or SPE-treated pregnant IL- $10^{-/-}$(upper panel) and wild-type mice (lower panel) are shown (original magnification, $\times 100$ ). H\&E stain shows capillary occlusion in the sPE-treated IL- $10^{-/-}$and wild-type animals with enlarged glomeruli and swollen endothelial cells compared with NPS-treated control mice. PAS-based staining of the sPE-treated mice shows inflammation of capillary endothelial cells (endotheliosis) in both IL-10 ${ }^{-1-}$ and wild-type animals. These pathological changes are absent in the NPS-treated mice. Similar results were observed with multiple serum samples. A representative image from the staining of at least three animals per group is shown. B: Circulating gd 17 mouse serum levels of sFlt-1 in response to a single-dose treatment with NPS (blue bar), sPE (magenta bar), and mPE (gray bar) are shown. Treatment with sPE induces excess production of sFlt-1 in IL-10-1- mice compared with NPS treatment without influencing wild-type counterparts. Treatment with $\mathrm{mPE}$ serum did not induce the production of sFlt-1 in either wild-type or IL-10 ${ }^{-1-}$ mice. C: Circulating gd 17 mouse serum levels of sEng in response to treatment with NPS, sPE, or mPE are shown in the graph. Treatment with SPE induces excess production of sEng both in IL-10 ${ }^{-/-}$mice as well as wild-type animals when compared with NPS treatment. Treatment with mPE induced moderate increase in the levels of sEng only in IL-10 ${ }^{-/-}$mice. All values are expressed as the mean \pm SD obtained from at least seven animals per treatment group. ${ }^{*} P<0.01$ or ${ }^{* *} P<0.05$ represent significance over control NPS-treated groups.

intraluminal spaces and hypertrophy of endocapillary cells was observed in both $\mathrm{IL}-10^{-1-}$ mice and wild type animals in response to preeclampsia serum. Similar changes were observed in pregnant mice treated with high doses of sFlt-1 and/or sEng (data not shown), in agreement with the reported observations in rats. ${ }^{49,51}$ Pregnant mice treated with normal pregnancy serum did not show any signs of kidney pathology (Figure 2A). Treatment with mild preeclampsia serum did not result in severe kidney pathology (data not shown), a possible explanation for the only moderate proteinuria readings observed (Figure 1B). The glomerular endotheliosis noted after administration of severe preeclampsia serum was consistent in all experiments and parallels the observations seen in renal biopsies in human preeclampsia. ${ }^{52}$

\section{Administration of Preeclampsia Serum Induces Excess Production of Mouse sFlt-1 and sEng}

Excess presence of sFlt-1 in circulation, possibly released by the placenta, has been detected in a signifi- cant proportion of patients with preeclampsia. It has been thought to be associated with endothelial dysfunction, hypertension, and proteinuria. 6,13,14,49 Moreover, sEng has been shown to act synergistically with sFlt-1 in causing preeclampsia-like features in an experimental model. ${ }^{51}$ It is possible that injection of preeclampsia serum in wild type or $\mathrm{IL}-10^{-1-}$ mice triggers excess production of these anti-angiogenic factors. Thus, we assessed the effect of preeclampsia serum on the circulating levels of mouse sFlt-1 and sEng by using a mouse-specific ELISA. Injection of severe preeclampsia serum significantly elevated the levels of mouse sFIt- 1 in $\mathrm{IL}-10^{-/-}$mice without affecting its production in wild type counterparts (Figure 2B). However, the serum levels of mouse sEng were significantly elevated both in wild type and IL-10 $10^{-/-}$mice in response to a single injection of severe preeclampsia serum (Figure 2C). In IL-10-/- mice, mild preeclampsia serum treatment led to relatively significant increase in sEng but not sFlt-1 (Figure 2C). In addition, this treatment did not cause sFlt-1 or sEng production in wild type animals. In this context, sEng has been shown to induce 
hypertension and proteinuria. However, fetal growth restriction in pregnant rats was observed only when sFlt-1 was co-administered with sEng. ${ }^{51}$ These observations suggest that combined elevation of both sFIt-1 and sEng in IL-10 deficient mice is likely to contribute to severe pathology affecting all maternal symptoms as observed in Figures 1 and 2.

\section{Nonpregnant Mice Are Resistant to Preeclampsia Serum-Associated Effects}

To confirm the pregnancy-specific nature of our observations, we injected normal or severe preeclampsia serum samples in nonpregnant wild type or $\mathrm{IL}-10^{-/-}$female mice. The animals were monitored for blood pressure, proteinuria, and circulating levels of anti-angiogenic factors on the seventh day after treatment. Treatment with serum did not cause elevated blood pressure (Figure $3 \mathrm{~A}$ ), proteinuria (Figure 3B), or alter the levels of sFlt-1 in either IL-10 $10^{-1-}$ or wild type animals (Figure $3 \mathrm{C}$ ). Moreover, the nonpregnant animals treated with severe preeclampsia serum did not experience renal pathology (data not shown), suggesting that the abnormalities observed in pregnant mice are linked pathophysiologically to the placenta.

\section{In Vivo Treatment with Preeclampsia Serum Perturbs Spiral Artery Transformation}

Spiral artery transformation is an essential feature of normal pregnancy that ensures the enhanced flow of nutrients and blood to the fetus. Poor remodeling of spiral arteries is a common histopathological feature of placentation in preeclampsia, IUGR, and preterm birth associated with preeclampsia. ${ }^{53-55}$ We assessed the morphological changes in the uteroplacental sections after staining with H\&E. The histological sections, marked mesometrium, decidua basalis, placenta, and spiral arteries, are shown in Figure 4A (upper panel, $\times 4$ magnification). The average area of spiral arteries in wild type and IL$10^{-1-}$ mice was quantified and is shown in Figure 4B. Treatment with severe preeclampsia serum but not normal pregnancy serum significantly reduced the circumference of modified spiral arteries and the total number of transformed spiral arteries in the mesometrial region in $\mathrm{IL}-10^{-1-}$ mice. There was a statistically insignificant effect of different treatments in the wild type animals as shown in Figure 4B. Morphometric analysis of the spiral arteries at higher magnification $(\times 40)$ using One Spot software (Figure 4A, lower panel) clearly showed that treatment of $\mathrm{IL}-10^{-1-}$ mice with severe preeclampsia serum significantly blocked the transformation of spiral arteries.

\section{Preeclampsia Serum Induces Hypoxia at the Maternal-Fetal Interface}

Preeclampsia is considered to be a two-stage disorder, characterized by placental hypoperfusion due to defec-
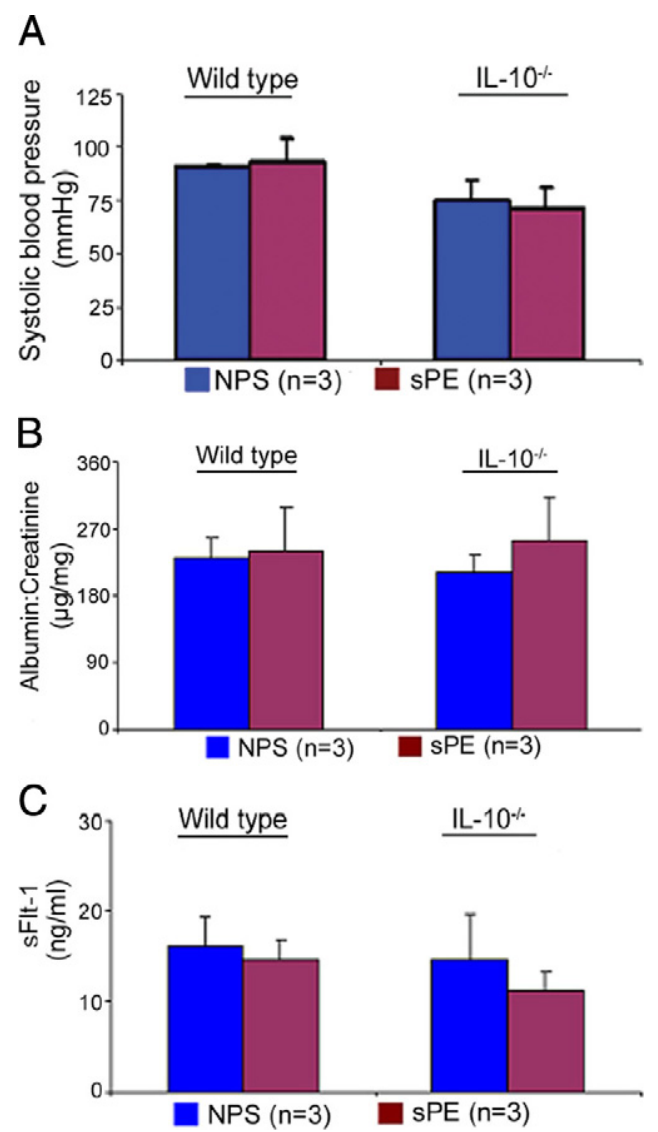

Figure 3. Severe preeclampsia serum does not induce disease-like symptoms in nonpregnant mice. Nonpregnant wild-type or IL- $10^{-/-}$female mice were injected with NPS or SPE samples. Seven days after a single administration as described for pregnant mice, blood pressure was monitored, and urine and serum samples were analyzed. A: No changes were observed in the readings of systolic blood pressure in nonpregnant mice irrespective of treatment with NPS (blue bar) or SPE (magenta bar). B: Proteinuria values from urine samples collected over a 24-hour period in response to different treatments are shown. Treatment with sPE did not induce significant proteinuria in either wild-type or IL-10 $0^{-1-}$ mice compared with NPS treatment C: Circulating mouse serum levels of soluble Flt-1(sFlt-1) in response to a single-dose treatment of NPS or SPE are shown. No significant differences were observed between NPS (blue bar) and sPE (magenta bar). All of the values were obtained from at least five animals per treatment group and are expressed as the mean $\pm \mathrm{SD}$. The numbers in parentheses indicate the number of different serum samples tested in the study.

tive spiral artery remodeling, causing hypoxic/ischemic injury to the placenta and resulting in excess production of soluble factors that contribute to the maternal syndrome. ${ }^{10,11}$ Since our findings indicate impaired spiral artery remodeling and excess production of sFlt-1, we hypothesized that treatment with severe preeclampsia serum could cause hypoxic injury in $\mathrm{IL}-10^{-1-}$ mice. We used a widely used method of hypoxia detection by EF5 (2-(2-nitro-1H-imidazol-1-yl)-N-(2,2,3,3,3-pentafluoropropyl) acetamide). ${ }^{45,46,50}$ As described in Materials and Methods, this compound is injected i.p. 4 hours before sacrificing the animal. Uteroplacental tissue was collected and stained with an antibody against EF5. A representative section of uteroplacental tissue from $\mathrm{IL}-10^{-1-}$ mice sacrificed on gd 14 and stained for EF5 is shown in Figure 5A ( $\times 4$ magnification). Preeclampsia serum was associated with significant hypoxic injury in uteroplacental tissue when compared with normal pregnancy serum 
A

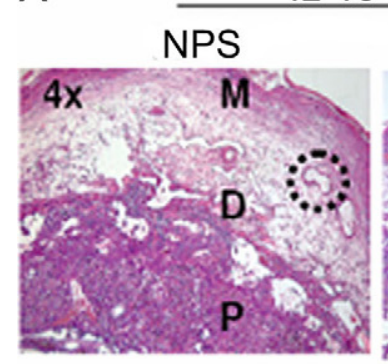

\section{NPS}

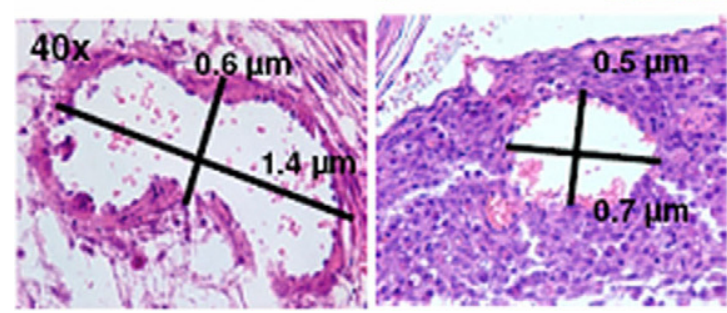

B

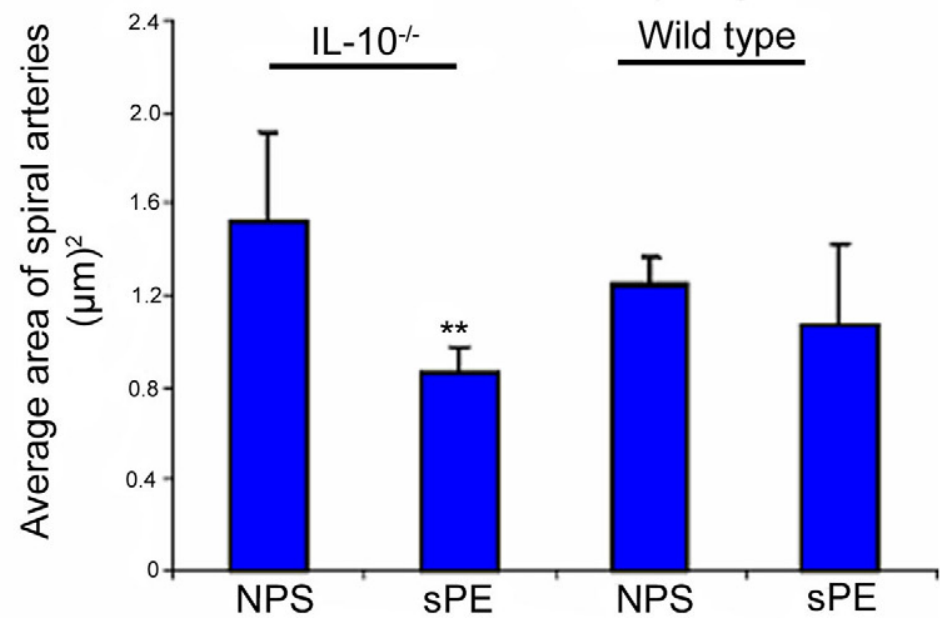

Figure 4. Preeclampsia serum blocks the spiral artery remodeling in pregnant IL-10 $10^{-/-}$mice. Pregnant wild-type and IL-10 ${ }^{-/-}$were injected with NPS, or sPE on gd 10, and uteroplacental units were analyzed on gd 13 as described in Materials and Methods. A: H\&E staining of a uteroplacental section from one representative NPS- or SPE-treated pregnant IL- $10^{-/-}$mouse is shown (upper panel; original magnification, $\times 4$ ), and the representative morphometry of a spiral artery indicated by a dotted circle is shown at higher magnification ( $\times 40$, lower panel). The lengths and widths of spiral arteries expressed in micrometers ( $\mu \mathrm{m})$ were measured and stamped by using SPOT Advanced software. Treatment with sPE resulted in poor remodeling of spiral arteries as indicated by their reduced size compared with NPS-treated control animals. B represents the average area of the spiral arteries of at least six spiral arteries per placental unit from three independent animals per treatment group. ${ }^{* *} P<0.05$ compared with the NPS-treated group. M, mesometrium; D, decidua basalis; P, placenta.

treatment as suggested by intense immuno-fluorescent staining for EF5. Since the response to hypoxia is regulated by hypoxia-inducible factors, we evaluated HIF $1 \alpha$ protein levels by Western blotting in IL-10 ${ }^{-1-}$ uteroplacental tissue collected on gd 12. As shown in Figure 5B, treatment with preeclampsia serum significantly induced the protein levels of HIF $1 \alpha$. These results suggest that preeclampsia serum induces significant hypoxia at the maternal-fetal interface in $\mathrm{IL}-10^{-1-}$ mice.

\section{Preeclampsia Serum Disrupts Endovascular Activity in Vitro}

Since preeclampsia serum impaired spiral artery remodeling and induced production of anti-angiogenic factors, we hypothesized that these serum samples would disrupt the endovascular interaction between endothelial cells and trophoblasts. We used an in vitro model that we recently established ${ }^{34,41,48}$ to assess serum samples from women with preeclampsia that were collected at 32 to 36 weeks and compared them with gestational agematched serum from normal pregnancies for their effect on endovascular interaction between endothelial cells and trophoblasts on matrigel. Normal pregnancy serum supported the endothelial cell-guided tube formation by first trimester trophoblast HTR8 cells (Figure 6A). In contrast, serum from severe or mild preeclampsia disrupted the endovascular cross talk between endothelial cells and trophoblasts (Figure 6B). Interestingly, the endovascular disrupting activity was independent of the serum levels of human sFlt-1 and sEng. Normal pregnancy serum spiked with amounts of recombinant sFlt-1 or sEng equal to that found in preeclampsia serum samples did not perturb tube formation (see Supplemental Figure S4 at http://ajp.amjpathol.org). However, it should be pointed out that endogenous sFIt-1 or sEng could differ from their recombinant counterparts in functional potency. We also ruled out the disruption of endovascular interaction by apoptotic cell death induced by serum. ${ }^{56}$ We analyzed the cytotoxic potential of serum samples on endothelial cells and first trimester HTR8 trophoblast cells by FACS analysis. As shown in Figure 6C, preeclampsia serum did not induce significant cell death as compared with normal pregnancy serum in either of the cell types.

\section{Gestational Age-Dependent Longitudinal Studies Confirm the Presence of Tube-Disrupting Activity at 12 to 14 Weeks}

Preeclampsia is typically diagnosed late in pregnancy. We propose that the molecular events leading to clinical manifestation of preeclampsia are likely to begin at earlier stages of pregnancy. Thus, we evaluated the sensitivity of our in vitro model to predict the gestational age-dependent effects of preeclampsia serum. We used serum samples drawn from patients at 12 to 14,22 to 27 , and 32 to 36 weeks of pregnancy who either experienced normal pregnancy or were given a diagnosis of preeclampsia after week 24. As shown in Figure 6D, normal pregnancy serum samples from different gestational ages support robust tube formation. In contrast, serum samples from preeclamptic women increasingly showed tube-disrupting activity that correlated with gestational age. Importantly, endovascular disruptive activity could be observed as early as 12 to 14 weeks' gestation. These results suggest that our in vitro three-dimensional tube formation assay can be successfully used to predict the onset of preeclampsia. 


\section{IL-10}
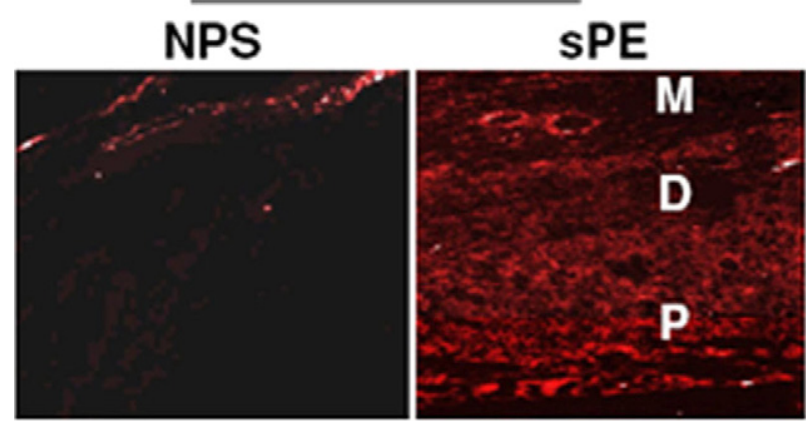

B

HIF 1a

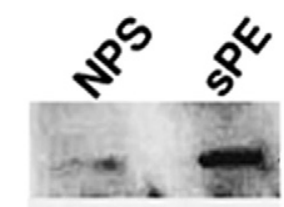

$\beta$-actin
Figure 5. Preeclampsia serum induces placental hypoxia in $\mathrm{IL}-10^{-/-}$mice Pregnant wild-type and IL-10 $10^{-1-}$ mice were injected with NPS or SPE on gd $10(n=3$ each $)$, and uteroplacental units were analyzed on gd 13. Animals were injected with EF5 as described in Materials and Methods. A: Immunofluorescence of a representative uteroplacental section stained with an EF5 specific antibody (original magnification, $\times 10$ ). Treatment with sPE significantly induced hypoxia in IL-10 $10^{-/-}$mice compared with NPS-treated mice. The treatment with sPE did not induce significant hypoxic injury in wild-type uteroplacental tissue. Note that EF5 staining was more prominent in the placental region (P) and that hypoxic injury was also visible in the decidua (D) and around the spiral arteries in the mesometrial region (M). B: Expression of HIF $1 \alpha$ in response to treatment with NPS and SPE in IL-10-1 placenta harvested on gd 12 is shown in a representative Western blot. $\beta$-actin is used as a loading control. Treatment with sPE significantly induced HIF $1 \alpha$ compared with NPS treatment and confirms the hypoxic effects seen with EF5 staining. These data represent at least three experiments.

\section{Discussion}

Here, we provide evidence that a single administration of preeclampsia serum $(0.1 \mathrm{ml})$ in pregnant $\mathrm{IL}-10^{-1-}$ mice induces the full spectrum of symptoms mirroring the human condition. Wild type and $\mathrm{IL}-10^{-1-}$ mice differed in their response to serum as the former only experienced preeclampsia-like symptoms without IUGR possibly related to lack of increase in serum sFlt-1 levels. This suggests that gene-environment interactions influence the course and programming of this heterogeneous condition. These observations are consistent with the clinical studies that suggest that preeclampsia and fetal growth restriction are often associated with a maternal profile that favors the prevalence of an anti-angiogenic phenotype (low PIGF, high sEng, and high sFIt-1).6,13,14 Interestingly, mild preeclampsia serum induced hypertension and proteinuria only in $\mathrm{IL}-10^{-1-}$ mice without significantly affecting their wild type counterparts, suggesting a gradation of the syndrome, which can be associated with IL-10 deficiency as an important predisposing factor for the severity of preeclampsia. Most importantly, our data for the first time provide evidence for induction of pregnancy-specific preeclampsia-like systemic symptoms as serum from patients with preeclampsia did not cause any effects in nonpregnant wild type or $\mathrm{IL}-10^{-1-}$ mice. This implies that the placenta plays a crucial role in regulating the onset of preeclampsia in response to administration of preeclampsia serum. The placental origin of preeclampsia further lends credence to the pregnancy-specific model described here. This further implies that onset of placental pathology is essential for release of soluble anti-angiogenic factors or other inflammatory regulators that are likely to cause maternal symptoms of hypertension and proteinuria.

In this context, recent studies have shown that administration of AT1-AAs from human preeclampsia serum samples could promote excess production of sFlt-1 leading to preeclampsia-like symptoms in mice. ${ }^{18,57}$ However, in the cohort of serum samples that we tested, the AT1 receptor antagonist losartan potassium or neutralizing seven-amino acid epitope binding peptide did not rescue serum-induced IUGR, hypertension, and proteinuria in IL-10 $0^{-/-}$pregnant mice (see Supplemental Figure S3 at $h$ ttp://ajp.amjpathol.org). The fact that only serum from the severe patients, but not mild preeclampsia or normal pregnancy, caused renal pathology in both wild type and $\mathrm{IL}-10^{-1-}$ mice again suggests that intrinsic gene-environment interactions are able to impart graded pathology in response to causative factors. The differential activity of serum samples from mild or severe preeclampsia could not be attributed to the varying concentrations of sFlt-1 and sEng because several preeclampsia serum samples showed values of these factors as the samples from normal pregnancy (see Supplemental Figure S1 at $h$ ttp://ajp.amjpathol.org).

Several studies have shown that hypoxia could be an upstream factor that promotes placental pathology including apoptosis, increase in oxidative stress, shedding of villous microparticles, and elevated production of antiangiogenic factors such as sFlt-1 and sEng. ${ }^{5,58,59} \mathrm{Hyp}-$ oxia-induced HIF $1 \alpha$ accumulation in the placenta is associated with defective trophoblast invasion into spiral arteries possibly resulting in remodeling defects and further ischemia. ${ }^{60}$ Moreover, HIF $1 \alpha$ has been shown to be expressed in the placenta from preeclamptic subjects. ${ }^{61}$ Hypoxia has also been shown to affect cytokine balance by reducing $\mathrm{IL}-10$ production and promoting $\mathrm{IL}-6$ and IL-8 in placental explants and trophoblasts. ${ }^{62,63}$ As evident from our studies, preeclampsia serum was indeed associated with placental hypoxia as indicated by EF5 incorporation in the decidua basalis and the junctional zone with significant induction of HIF $1 \alpha$ in IL-10 ${ }^{-1-}$ mice. We did not observe a similar effect in the wild type counterparts. Both Flt-1 and Eng genes contain hypoxiainducible factor- 1 binding sites and are known to be under hypoxic regulation. ${ }^{64}$ Specifically, hypoxia has been shown to trigger HIF $1 \alpha$ expression with excess production of sFlt-1 and sEng in trophoblasts from preeclamptic placenta. ${ }^{64,65}$ Thus, placental hypoxic injury with preeclampsia serum could be a possible cause for

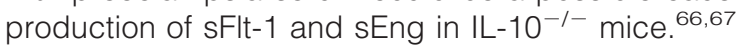

As a consequence of the placental hypoxic injury, our observations on impaired spiral artery remodeling in IL$10^{-1-}$ mice in response to preeclampsia serum are noteworthy. In the human condition, impaired spiral artery 
A

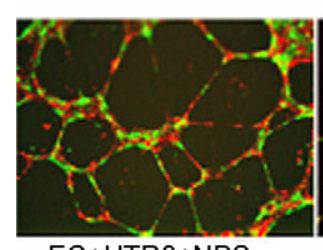

EC+HTR8+NPS $(n=23)$

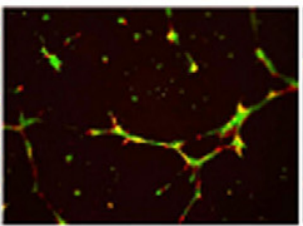

$\mathrm{EC}+\mathrm{HTR} 8+\mathrm{sPE}$

$(n=20)$

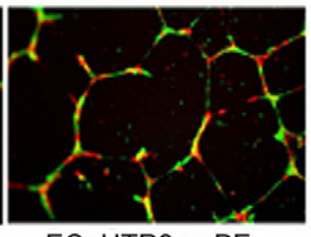

$\mathrm{EC}+\mathrm{HTR} 8+\mathrm{mPE}$ $(n=18)$
B

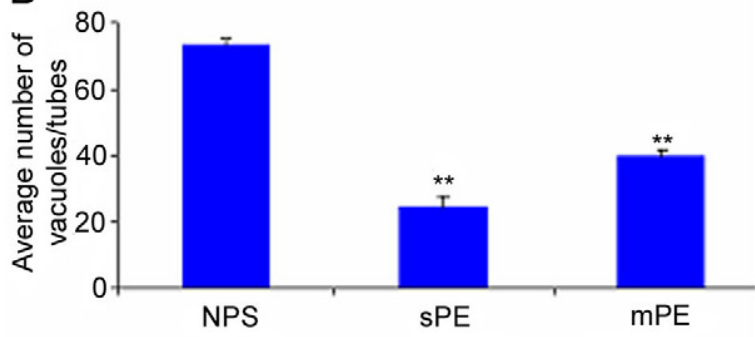

C
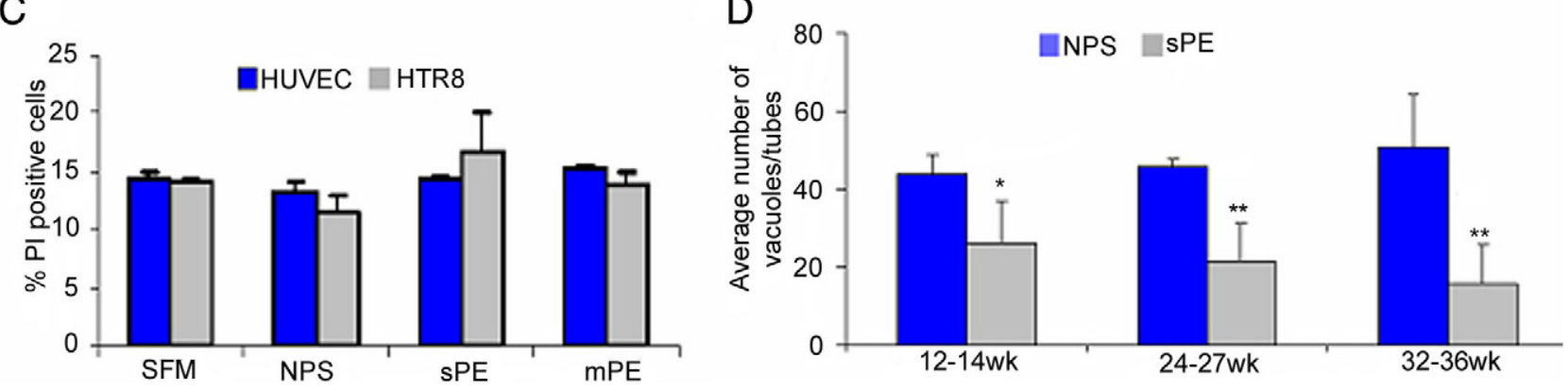

Figure 6. Preeclampsia serum disrupts endovascular interaction between trophoblasts and endothelial cells in vitro. A: Human umbilical vein endothelial cells (EC; labeled red) and first-trimester human trophoblasts (HTR8; labeled green) were cultured overnight on Matrigel in the presence of gestational age-matchec NPS, sPE, or mPE serum. Capillary tube formation was recorded as described in Materials and Methods. Representative figures of EC-directed tube formation by HTR8 cells (original magnification, $\times 4$ ) are shown. NPS significantly supported tube formation, whereas sPE and mPE serum disrupted this interaction, albeit in a mild or severe pathology-dependent manner. B shows the quantification of dual cell endovascular tube formation in response to different serum samples. The average number of tubes/vacuoles formed was quantified by counting the number of tube-like structures formed by connected capillary bridge in four different fields (original magnification, $\times 4$ ) as described in Materials and Methods and represents multiple experiments. C: Cytotoxic potential of NPS and sPE on EC and HTR8 by propidium iodide (PI) staining was analyzed by FACS and represented here as \% PI positive cells. Treatment with sPE or NPS did not induce cytotoxicity in either EC or HTR8. D: Longitudinal studies involving pregnancy serum samples from weeks 12 to 14 ( $n=18)$, 24 to 27 ( $n=5$ ), or 32 to 36 ( $n=22$ ) weeks of gestation were tested for supporting tube formation. These samples were from women who were later diagnosed with preeclampsia. Data are represented as a comparative analysis between these samples and those from gestational age-matched normal pregnancies. The average number of tubes/vacuoles formed was quantified and plotted. As seen in $\mathbf{D}$, unlike NPS, the tube disrupting activity in preeclampsia serum could be traced back to 12 to 14 weeks of pregnancy. All of the values are expressed as the mean $\pm \mathrm{SD} .{ }^{*} P<0.01$ or ${ }^{* *} P<0.05$ compared with the respective control NPS-treated group.

remodeling is a clinical histological feature possibly due to inefficient trophoblast invasion. ${ }^{53,54}$ Although the trophoblast invasion in mice is relatively shallow as compared with humans, multiple studies with mice have shown that spiral artery remodeling occurring during normal pregnancy could be perturbed by uterine natural killer cell dysregulation and by inhibition of the water channel, aquaporin 1, at the maternal-fetal interface. ${ }^{34,37}$ It is thus possible that in preeclampsia serum-treated mice, dysregulated cross talk between uterine natural killer cells and endothelial cells as a result of hypoxic injury or altered angiogenesis-cytokine machinery, not trophoblast invasion, may be a major regulator of spiral artery remodeling. In the context of human pregnancy, we have been able to demonstrate an in vitro model of impaired cross talk between trophoblasts and endothelial cells by preeclampsia serum. In this model, extravillous trophoblasts from first trimester uniquely fingerprint the endothelial cell-guided tube formation under pregnancy milieu provided by normal pregnancy serum. ${ }^{41}$ Under identical conditions, preeclampsia serum from both mild and severe conditions consistently disrupted this endovascular cross talk. The disruption of tube formation by preeclampsia serum was graded according to the severity of the disease and was, at least partly, independent of the serum levels of sFlt-1, sEng, vascular endothelial growth factor, or PIGF (data not shown). Importantly, using this bioassay with samples from a longitudinal study, we demonstrated disruption of endovascular trophoblast interaction by serum samples from patients with preeclampsia collected as early as 12 to 14 weeks of pregnancy. This observation is significant in view of the fact that the disease is clinically manifest as symptoms that typically occur only in the third trimester of pregnancy. Moreover, the heterogeneous nature of the disease has hampered the search for discovery of "biomarkers" applicable to the majority of patient population. In this regard, our in vitro predictive assay using serum from pregnant women is likely to provide a robust approach to study disease-related changes and to blueprint placental pathology. Longitudinal studies and a larger collection of patient serum samples that validate the bioassay may have the potential to identify a functional biomarker. In this regard, we are currently evaluating serum samples from 12 to 14 weeks' gestation for their ability to cause preeclampsia-like symptoms in IL-10 ${ }^{-1-}$ mice. Identification of causative factor(s) present in preeclampsia serum responsible for the in vivo and in vitro observations presented here is currently under investigation.

Collectively, our data support the "blueprint" concept of preeclampsia serum as demonstrated here in a novel semihumanized mouse model of preeclampsia and in an in vitro bioassay for predicting the onset of preeclampsia. Since a multifactorial etiology has been widely discussed for preeclampsia, we propose that the pregnancy-specific $\mathrm{IL}-10^{-1-}$ mouse model that closely mirrors the hu- 
man condition is suitable for now studying the complex myriad of molecular events and for testing novel therapeutic interventions. This model could be further improved by using the telemetry approach in place of the tail cuff blood pressure measuring device and by better characterizing the renal histology using electron microscopy. Our results also suggest that a possible role of IL-10 should be investigated in preeclampsia in humans.

\section{Acknowledgments}

We are grateful to all of the mothers participating in this study. We thank Udo Markert, Brenna Anderson, and Jared Robbins for a critical reading of the article.

\section{References}

1. Sibai B, Dekker G, Kupferminc M: Pre-eclampsia. Lancet 2005, 365:785-799

2. Redman CW, Sargent IL: Latest advances in understanding preeclampsia. Science 2005, 308:1592-1594

3. Ilekis JV, Reddy UM, Roberts JM: Preeclampsia - a pressing problem: an executive summary of a National Institute of Child Health and Human Development workshop. J Reprod Sci 2007, 14:508-523

4. Noris M, Perico N, Remuzzi G: Mechanisms of disease: pre-eclampsia. Nat Clin Pract Nephrol 2005, 1(2):98-114

5. Redman CWG, Sargent IL: Placental debris, oxidative stress and preeclampsia. Placenta 2000, 21:597-602

6. Levine RJ, Maynard SE, Qian C, Lim KH, England LJ, Yu KF, Schisterman EF, Thadhani R, Sachs BP, Epstein FH, Sibai BM, Sukhatme VP, Karumanchi SA: Circulating angiogenic factors and the risk of preeclampsia. N Engl J Med 2004, 350:672-683

7. Roberts JM, Cooper DW: Pathogenesis and genetics of pre-eclampsia. Lancet 2001, 357:53-56

8. Hiby SE, Walker JJ, O'Shaughnessy KM, Redman CW, Carrington M, Trowsdale J, Moffett A: Combinations of maternal KIR and fetal HLA-C genes influence the risk of preeclampsia and reproductive success. J Exp Med 2004, 200:957-965

9. Kalkunte S, Chichester CO, Gotsch F, Sentman CL, Romero R, Sharma S: Evolution of non-cytotoxic uterine natural killer cells. Am J Reprod Immunol 2008, 59:425-432

10. Redman CW: Immunological aspects of pre-eclampsia. Baillieres Clin Obstet Gynaecol 1992, 6:601-615

11. Roberts JM, Hubel CA: The two stage model of preeclampsia: variations on the theme. Placenta 2009, 23:S32-S37

12. Zhou Y, McMaster M, Woo K, Janatpour M, Perry J, Karpanen T, Alitalo K, Damsky C, Fisher SJ: Vascular endothelial growth factor ligands and receptors that regulate human cytotrophoblast survival are dysregulated in severe preeclampsia and hemolysis, elevated liver enzymes, and low platelets syndrome. Am J Pathol 2002, 160:1405-1423

13. Levine RJ, Lam C, Qian C, Yu KF, Maynard SE, Sachs BP, Sibai BM, Epstein FH, Romero R, Thadhani R, Karumanchi SA; CPEP Study Group: Soluble endoglin and other circulating anti-angiogenic factors in preeclampsia. N Engl J Med 2006, 355:992-1005

14. Romero R, Nien JK, Espinoza J, Todem D, Fu W, Chung H, Kusanovic JP, Gotsch F, Erez O, Mazaki-Tovi S, Gomez R, Edwin S, Chaiworapongsa T, Levine RJ, Karumanchi SA: A longitudinal study of angiogenic (placental growth factor) and anti-angiogenic (soluble endoglin and soluble vascular endothelial growth factor receptor-1) factors in normal pregnancy and patients destined to develop preeclampsia and deliver a small for gestational age neonate. J Matern Fetal Neonatal Med 2008, 21:9-23

15. Solomon CG, Seely EW: Preeclampsia: searching for the cause. N Engl J Med 2004, 350:641-642

16. Wallukat G, Homuth V, Fischer T, Lindschau C, Horstkamp B, Jüpner A, Baur E, Nissen E, Vetter K, Neichel D, Dudenhausen JW, Haller H, Luft FC: Patients with preeclampsia develop agonistic autoantibodies against the angiotensin AT1 receptor. J Clin Invest 1999, 103:945-952

17. Herse F, Staff AC, Hering L, Müller DN, Luft FC, Dechend R: AT1receptor autoantibodies and uteroplacental RAS in pregnancy and pre-eclampsia. J Mol Med 2008, 86:697-703

18. Zhou CC, Zhang $Y$, Irani RA, Zhang H, Mi T, Popek EJ, Hicks MJ, Ramin SM, Kellems RE, Xia Y: Angiotensin receptor agonistic autoantibodies induce pre-eclampsia in pregnant mice. Nat Med 2008, 14:855-862

19. Parikh SM, Karumanchi SA: Putting pressure on pre-eclampsia. Nat Med 2008, 14:810-812

20. Rossant J, Cross JC: Placental development: lessons from mouse mutants. Nat Rev Genet 2001, 2:538-548

21. Kanasaki K, Palmsten K, Sugimoto H, Ahmad S, Hamano Y, Xie L, Parry S, Augustin HG, Gattone VH, Folkman J, Strauss JF, Kalluri R: Deficiency in catechol-O-methyltransferase and 2-methoxyoestradiol is associated with pre-eclampsia. Nature 2008, 453:1117-1121

22. Hayakawa S, Fujikawa T, Fukuoka H, Chisima F, Karasaki-Suzuki M, Ohkoshi E, Ohi H, Kiyoshi Fujii T, Tochigi M, Satoh K, Shimizu T, Nishinarita S, Nemoto N, Sakurai I: Murine fetal resorption and experimental pre-eclampsia are induced by both excessive Th1 and Th2 activation. J Reprod Immunol 2000, 47:121-138

23. Takimoto E, Ishida J, Sugiyama F, Horiguchi H, Murakami K, Fukamizu A: Hypertension induced in pregnant mice by placental renin and maternal angiotensinogen. Science 1996, 274:995-998

24. Kanayama N, Takahashi K, Matsuura T, Sugimura M, Kobayashi T, Moniwa N, Tomita M, Nakayama K: Deficiency in p57Kip2 expression induces preeclampsia-like symptoms in mice. Mol Hum Reprod 2002, 8:1129-1135

25. Davisson RL, Hoffmann DS, Butz GM, Aldape G, Schlager G, Merrill DC, Sethi S, Weiss RM, Bates JN: Discovery of a spontaneous genetic mouse model of preeclampsia. Hypertension 2002, 39:337-342

26. Podjarny E, Losonczy G, Baylis C: Animal models of preeclampsia. Semin Nephrol 2004, 24:596-606

27. Falcao S, Solomon C, Monat C, Bérubé J, Gutkowska J, Lavoie JL: Impact of diet and stress on the development of preeclampsia-like symptoms in p57kip2 mice. Am J Physiol Heart Circ Physiol 2009, 296: $\mathrm{H} 119-\mathrm{H} 126$

28. Hanna N, Hanna I, Hleb M, Wagner E, Dougherty J, Balkundi D, Padbury J, Sharma S: Gestational age-dependent expression of IL-10 and its receptor in human placental tissues and isolated cytotrophoblasts. J Immunol 2000, 164:5721-5728

29. Hanna N, Bonifacio L, Weinberger B, Reddy P, Murphy S, Romero R, Sharma S: Evidence for interleukin-10-mediated inhibition of cyclooxygenase-2 expression and prostaglandin production in preterm human placenta. Am J Reprod Immunol 2006, 55:19-27

30. Plevyak M, Hanna N, Mayer S, Murphy S, Pinar H, Fast L, Ekerfelt C, Ernerudh J, Berg G, Matthiesen L, Sharma S: Deficiency of decidual IL-10 in first trimester missed abortion: a lack of correlation with the decidual immune cell profile. Am J Reprod Immunol 2002, 47: 242-250

31. Robertson SA, Skinner RJ, Care AS: Essential role for IL-10 in resistance to lipopolysaccharide-induced preterm labor in mice. J Immunol 2006, 177:4888-4896

32. Murphy SP, Hanna NN, Fast LD, Shaw SK, Berg G, Padbury JF Romero R, Sharma S: Evidence for participation of uterine natural killer cells in the mechanisms responsible for spontaneous preterm labor and delivery. Am J Obstet Gynecol 2009, 200:308, e1-9

33. Thaxton JE, Romero R, Sharma S: TLR9 activation coupled to IL-10 deficiency induces adverse pregnancy outcomes. J Immunol 2009, 183:1144-1154

34. Tewari N, Kalkunte S, Murray DW, Sharma S: The water channel aquaporin 1 is a novel molecular target of polychlorinated biphenyls for in utero anomalies. J Biol Chem 2009, 284:15224-15232

35. Hennessy A, Pilmore HL, Simmons LA, Painter DM: A deficiency of placental IL-10 in preeclampsia. J Immunol 1999, 163:3491-3495

36. Makris A, Xu B, Yu B, Thornton C, Hennessy A: Placental deficiency of interleukin-10 (IL-10) in preeclampsia and its relationship to an IL10 promoter polymorphism. Placenta 2006, 27:445-451

37. Ashkar AA, Di Santo JP, Croy BA: Interferon $\gamma$ contributes to initiation of uterine vascular modification, decidual integrity, and uterine natural killer cell maturation during normal murine pregnancy. J Exp Med 2000, 192:259-269

38. Hanna J, Goldman-Wohl D, Hamani Y, Avraham I, Greenfield C, 
Natanson-Yaron S, Prus D, Cohen-Daniel L, Arnon TI, Manaster I, Gazit R, Yutkin V, Benharroch D, Porgador A, Keshet E, Yagel S, Mandelboim O: Decidual NK cells regulate key developmental processes at the human fetal-maternal interface. Nat Med 2006, 12:1065-1074

39. Moffett A, Loke C: Immunology of placentation in eutherian mammals. Nat Rev Immunol 2006, 6:584-594

40. Burton GJ, Woods AW, Jauniaux E, Kingdom JC: Rheological and physiological consequences of conversion of the maternal spiral arteries for uteroplacental blood flow during human pregnancy. Placenta 2009, 30:473-482

41. Kalkunte S, Lai Z, Tewari N, Chichester C, Romero R, Padbury J, Sharma S: In vitro and in vivo evidence for lack of endovascular remodeling by third trimester trophoblasts. Placenta 2008, 29 871-878

42. American College of Obstetricians and Gynecologists. ACOG practice bulletin. Diagnosis and management of preeclampsia and eclampsia. Int J Gynaecol Obstet 2002, 77:67-75

43. Wedgbury K, Waller-Jones T: Measuring blood pressure using automated sphygmomanometer. Br J Nurs 2008, 17:714-718

44. Murphy SP, Fast LD, Hanna NN, Sharma S: Uterine NK cells mediate inflammation-induced fetal demise in IL-10-null mice. J Immunol 2005, 175:4084-4090

45. Koch CJ, Evans SM, Lord EM: Oxygen dependence of cellular uptake of EF5 [2-(2-nitro-1H-imidazol-1-yl)-N-(2,2,3,3,3-pentafluoropropyl) acetamide]: analysis of drug adducts by fluorescent antibodies vs bound radioactivity. Br J Cancer 1995, 72:869-874

46. Koch CJ, Lord EM, Shapiro IM, Clyman RI, Evans SM: Imaging hypoxia and blood flow in normal tissues. Adv Exp Med Biol 1997. 428:585-593

47. Graham CH, Hawley TS, Hawley RG, MacDougall JR, Kerbel RS, Khoo N, Lala PK: Establishment and characterization of first trimester human trophoblast cells with extended lifespan. Exp Cell Res 1993 206:204-211

48. Kalkunte S, Mselle TF, Norris WE, Wira CR, Sentman CL, Sharma S: VEGF $C$ facilitates immune tolerance and endovascular activity of human uterine NK cells at the maternal-fetal interface. J Immunol 2009, 182:4085-4092

49. Maynard SE, Min JY, Merchan J, Lim KH, Li J, Mondal S, Libermann TA, Morgan JP, Sellke FW, Stillman IE, Epstein FH, Sukhatme VP, Karumanchi SA: Excess placental soluble fms-like tyrosine kinase 1 (sFlt1) may contribute to endothelial dysfunction, hypertension, and proteinuria in preeclampsia. J Clin Invest 2003, 111:649-658

50. Schäffer L, Vogel J, Breymann C, Gassmann M, Marti HH: Preserved placental oxygenation and development during severe systemic hypoxia. Am J Physiol Regul Integr Comp Physiol 2006, 290:R844-R851

51. Venkatesha S, Toporsian M, Lam C, Hanai J, Mammoto T, Kim YM, Bdolah Y, Lim KH, Yuan HT, Libermann TA, Stillman IE, Roberts D, D'Amore PA, Epstein FH, Sellke FW, Romero R, Sukhatme VP, Letarte $\mathrm{M}$, Karumanchi SA: Soluble endoglin contributes to the pathogenesis of preeclampsia. Nat Med 2006, 12:642-649

52. Gaber LW, Spargo BH, Lindheimer MD: Renal pathology in preeclampsia. Baillieres Clin Obstet Gynaecol 1994, 8:443-468

53. Brosens I, Dixon HG, Robertson WB: Fetal growth retardation and the arteries of the placental bed. Br J Obstet Gynaecol 1977, 84:656-663
54. Meekins JW, Pijnenborg R, Hanssens M, McFadyen IR, van Asshe A: A study of placental bed spiral arteries and trophoblast invasion in normal and severe pre-eclamptic pregnancies. Br J Obstet Gynaecol 1994, 101:669-674

55. Kim YM, Bujold E, Chaiworapongsa T, Gomez R, Yoon BH, Thaler HT, Rotmensch S, Romero R: Failure of physiologic transformation of the spiral arteries in patients with preterm labor and intact membranes. Am J Obstet Gynecol 2003, 189:1063-1069

56. Rampersad R, Barton A, Sadovsky Y, Nelson DM: The C5b-9 membrane attack complex of complement activation localizes to villous trophoblast injury in vivo and modulates human trophoblast function in vitro. Placenta 2008, 29:855-861

57. Zhou CC, Ahmad S, Mi T, Abbasi S, Xia L, Day MC, Ramin SM, Ahmed A, Kellems RE, Xia Y: Autoantibody from women with preeclampsia induces soluble Fms-like tyrosine kinase-1 production via angiotensin type 1 receptor and calcineurin/nuclear factor of activated T-cells signaling. Hypertension 2008, 51:1010-1019

58. Hung TH, Skepper JN, Charnock-Jones SD, Burton GJ: Hypoxia reoxygenation: a potent inducer of apoptotic changes in the human placenta and possible etiological factor in preeclampsia. Circ Res 2002, 90:1274-1281

59. Nevo O, Soleymanlou N, Wu Y, Xu J, Kingdom J, Many A, Zamudio S, Caniggia I: Increased expression of sFlt-1 in in vivo and in vitro models of human placental hypoxia is mediated by HIF-1. Am J Physiol Regul Integr Comp Physiol 2006, 291(4):R1085-1093

60. Caniggia I, Mostachfi H, Winter J, Gassmann M, Lye SJ, Kuliszewski M, Post M: Hypoxia-inducible factor-1 mediates the biological effects of oxygen on human trophoblast differentiation through TGFbeta-3. $\mathrm{J}$ Clin Invest 2000, 105:577-587

61. Rajakumar A, Whitelock KA, Weissfeld LA, Daftary AR, Markovic N, Conrad KP: Selective overexpression of the hypoxia-inducible transcription factor, HIF-2alpha, in placentas from women with preeclampsia. Biol Reprod 2001, 64:499-506

62. Royle C, Lim S, Xu B, Tooher J, Ogle R, Hennessy A: Effect of hypoxia and exogenous IL-10 on the pro-inflammatory cytokine TNF-alpha and the anti-angiogenic molecule soluble Flt-1 in placental villous explants. Cytokine 2009, 47:56-60

63. Bowen RS, Gu Y, Zhang Y, Lewis DF, Wang Y: Hypoxia promotes interleukin- 6 and -8 but reduces interleukin-10 production by placental trophoblast cells from preeclamptic pregnancies. J Soc Gynecol Investig 2005, 12:428-432

64. Gu Y, Lewis DF, Wang Y: Placental productions and expressions of soluble endoglin, soluble fms-like tyrosine kinase receptor-1, and placental growth factor in normal and preeclamptic pregnancies. J Clin Endocrinol Metab 2008, 93:260-266

65. Xiong Y, Liebermann DA, Tront JS, Holtzman EJ, Huang Y, Hoffman B, Geifman-Holtzman O: Gadd45a stress signaling regulates sFlt-1 expression in preeclampsia. J Cell Physiol 2009, 220:632-639

66. Sharma S, Norris WE, Kalkunte S: Beyond the threshold: an etiological bridge between hypoxia and immunity in preeclampsia. J Reprod Immunol 2010, 85:112-116

67. Kalkunte S, Lai Z, Norris WE, Pietras LA, Tewari N, Boij R, Neubeck S Markert UR, Sharma S: Novel approaches for mechanistic understanding and predicting preeclampsia. J Reprod Immunol 2009, 83:134-138 